\title{
伝達関数合成法を用いた衝撃応答スペクトラムの予測における合成成分の選択
}

\author{
柳瀬 恵一 ${ }^{* 1, * 3}$, 福田 達輝*2, 岩佐 貴史 ${ }^{* 3}$
}

\section{Method for selecting axes for prediction of shock response spectrum using transfer function synthesis}

\author{
Keiichi YANAGASE ${ }^{* 1, * 3}$, Tatsuki FUKUDA ${ }^{* 2}$ and Takashi IWASA*3 \\ ${ }^{* 1}$ Japan Aerospace Exploration Agency \\ 2-1-1 Sengen, Tsukuba-shi, Ibaraki 305-8505, Japan \\ ${ }_{2, * 3}^{*}$ Department of Mechanical and Aerospace Engineering, Tottori University \\ 4-101 Koyama-cho, Minami, Tottori-shi, Tottori 680-8552, Japan
}

Received: 2 October 2020; Revised: 7 December 2020; Accepted: 5 January 2021

\begin{abstract}
Effects of the rotational component on a prediction result of the shock response spectrum given by a transfer function synthesis method are discussed. Shock environment on two structure models, which are a plate model connected by two flat plates and a shock tester model installing a test specimen, is analyzed. The transfer functions of the substructures in these models are initially computed and are synthesized to predict the shock response spectrum in the coupled structure. In the synthesis analysis without the rotational component, the prediction accuracy of the shock response spectrum in the plate model significantly decreases, whereas that in the shock tester model is unaffected. This is attributed to the fact that the shock tester model has high flexible rigidity originated from its structural configuration. This result indicates that the shock response spectrum on the shock tester model can be predicted with sufficient accuracy by only synthesizing the transfer functions with the translation component.
\end{abstract}

Keywords : Spacecraft, Environmental test, Shock, Shock test, Substructure synthesis method

\section{1. 緒言}

ロケットの各部分離，人工衛星の太陽電池パドルやアンテナ等の展開では，保持部の解放を担う機構内部の部 品の切断・衝突や，保持されている構造体のひずみエネルギーが瞬時に解放されることにより，大きな衝撃が発 生する. そのため, 宇宙機搭載機器はシステム組立前に機器単体の衝撃而性を確認する必要がある. 機器単体の 衝撃試験は，フライト品と同等の衝撃源や搭載環境を模擬することはコスト的に困難であり，図 1 に示寸機械的 インパクト試験法等の実環境とは異なる環境での試験が行われる (宇宙航空研究開発機構, 2017).

しかしながら，このような手法を用いた衝撃試験では，衝撃源および衝撃を伝搬させる構造のいずれもが実際 の宇宙機とは異なり，試験条件として提示される衝撃応答スペクトラム（Shock Response Spectrum：SRS）を合わ せ込むことが困難であることが多い，試験では，被試験体の質量ダミーを用いて SRS の調整を行うことが一般的 であるが，質量ダミーにはアルミ合金等の金属塊が用いられることが多く，搭載機器と振動特性が同等とは言え ないため, 最終的な調整は実際の搭載機器を用いて行われる場合もある。このような場合では，搭載機器に過剩 な負荷を与えてしまうことが懸念される. そのため, 衝撃試験を行う前に SRS の予測を行う方法が望まれている. また，予測が可能となれば試験機の調整作業の手間も大きく改善されると考えられる.

No.20-00341 [DOI:10.1299/transjsme.20-00341], J-STAGE Advance Publication date : 15 January, 2021

${ }^{* 1}$ 正員, 宇宙航空研究開発機構（厂305-8505 茨城県つくば市千現 2-1-1）

*2 学生員, 鳥取大学大学院 工学研究科（干680-8552 鳥取県鳥取市湖山町南 4-101）

*3 正員, 鳥取大学大学院 工学研究科

E-mail of corresponding author: yanagase.keiichi@jaxa.jp 
SRS の予測手法については，ロケットと衛星の分離部や火工品デバイス等の衝撃源の予測を行う方法（Iwasa and Shi, 2008, Wang et al., 2017 および Lee et al., 2018）や，宇宙機内部の機器搭載部の SRS を予測する方法（Lee et al., 2012) などが提案されているが，いずれも形状が確定している構造体に対して振動特性や伝搬減衰を考慮して 予測を行うものである。試験では，事前に既知な構造体は試験機のみであり，試験に供される搭載機器の振動特 性は毎回異なるため, 試験機と搭載機器の連成応答を効率良く見積もる方法が必要である.また，試験機上の衝 撃加振においては, 衝撃印加点と被試験体との距離は数から十数 $\mathrm{cm}$ 程度と近いため, 伝搬減衰の影響は小さく, 専ら振動特性の変化が支配的であると考えられる.

そこで筆者らは，試験機および搭載機器の単体の振動特性から，伝達関数合成法（Nagamatsu et al., 1983）を用 いて試験機上で発生する SRS を事前に予測する手法（柳瀬他，2019）を検討している．伝達関数合成法は，ハン マリング試験等の実験で得られた伝達関数と有限要素解析等の数值計算で得られた伝達関数とを混用できるため 設計開発のあらゆる段階で活用できると考えられ利便性が高い. 例えば, 設計初期は有限要素解析結果で予測を 行い，製作後は試験で伝達関数を取得し，予測精度を上げるといったことが可能である.

伝達関数合成法で正確な予測結果を得るためには並進 3 成分および回転 3 成分の 6 成分の振動応答を合成する 必要がある（沖津他，1988）。しなしながら，実際の試験で 6 成分全ての振動応答を取得することは，取得作業と 計算過程が煩雑になり, 事前予測の利便性が失われてしまう。そこで, 本稿では伝達関数合成法を用いて SRS を 予測する場合に実用上必要な振動志答成分について数值解析を用いて検討した結果を報告する.

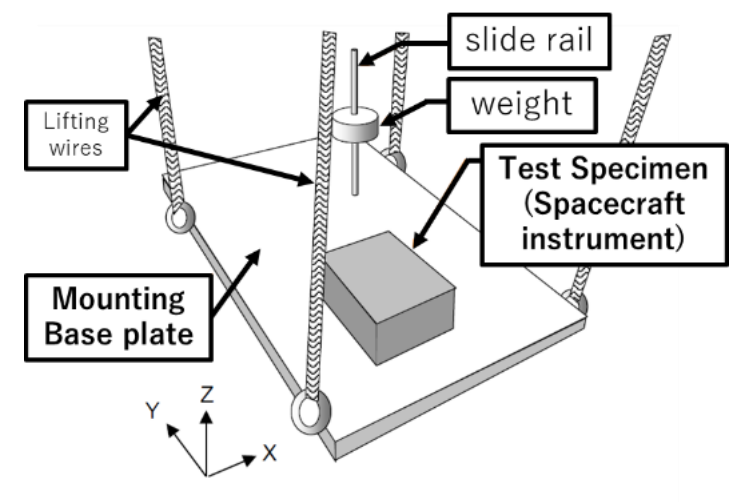

Fig. 1 A drop weight shock tester (Japan Aerospace Exploration Agency, 2017).

\section{2. 伝達関数合成法を用いた加速度応答の計算}

伝達関数合成法（長松，大熊，1991）を活用した加速度応答の計算方法を以下に示す. 図 2 に示す 2 分系のモ デルにおいて, 分系 $\mathrm{A}$ を衝撃試験機, 分系 $\mathrm{B}$ を搭載機器（以下, 被試験体）とし, $n$ 個の点で締結されていると する. 点 $i$ と点 $j$ の伝達関数を $G_{i j}$ とすると, 点 $j$ を加振力 $F_{j}$ で加振した場合の点 $i$ の加速度応答 $A_{i}$ は式 (1) となる.

$$
A_{i}=G_{i j} F_{j}
$$

ここで, 分系 $\mathrm{A}$ で観測される結合点 $i$ の加速度応答を $A_{i}^{A}$, 分系 $\mathrm{A}$ と分系 $\mathrm{B}$ の結合点 $i$ て分系 $\mathrm{A}$ が受ける作用力を $R_{i} \quad(i=1 \sim n)$ とすると

$$
\left\{\begin{array}{c}
A_{1}^{A} \\
\vdots \\
A_{n}^{A}
\end{array}\right\}=\left[\begin{array}{ccc}
G_{11}^{A} & \cdots & G_{1 n}^{A} \\
\vdots & \ddots & \vdots \\
G_{n 1}^{A} & \cdots & G_{n n}^{A}
\end{array}\right]\left\{\begin{array}{c}
R_{1} \\
\vdots \\
R_{n}
\end{array}\right\}+\left\{\begin{array}{c}
G_{1 f}^{A} \\
\vdots \\
G_{n f}^{A}
\end{array}\right\} F_{f}
$$




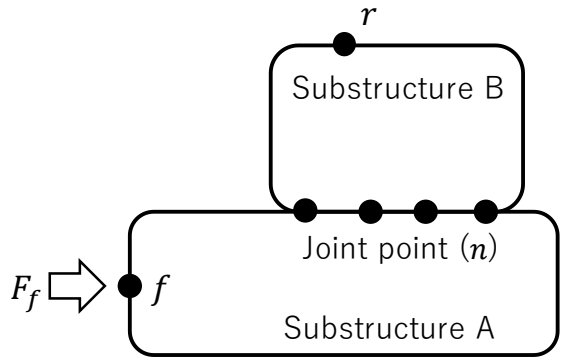

(a) Joint model
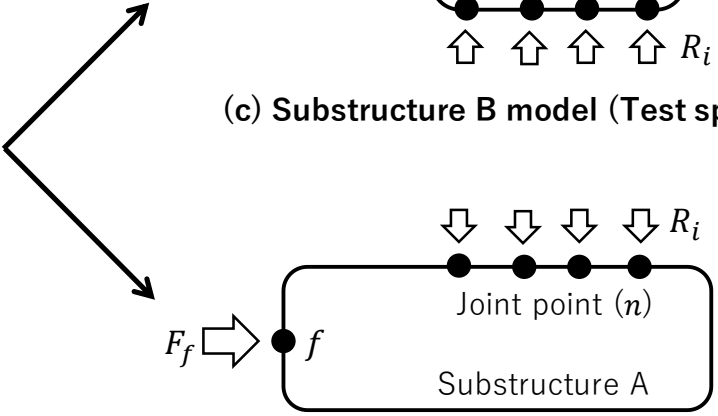

(b) Substructure A model (Test apparatus)

Fig. 2 Structure model consisting of two substructures. $f$ is the excitation point, $r$ is the observation point, and $F_{f}$ is the excitation force. $R i$ is the internal force between A and B. $n$ is number of joint points.

となる.ここで, $G_{n n}^{A}$ は図 $2(\mathrm{~b})$ で示す分系 $\mathrm{A}$ の分系 $\mathrm{B}$ との結合点を加振することで取得される伝達関数であり, $G_{n f}^{A}$ は分系 $\mathrm{A}$ の加振点 $f$ を加振した際の分系 $\mathrm{B}$ との結合点の伝達関数である. また, 分系 $\mathrm{B}$ においても図 $2(\mathrm{c})$ に示す分系 A との結合点を加振することによって結合点と観測点 $r$ の伝達関数を取得し，

$$
\left\{\begin{array}{c}
A_{1}^{B} \\
\vdots \\
A_{n}^{B}
\end{array}\right\}=-\left[\begin{array}{ccc}
G_{11}^{B} & \cdots & G_{1 n}^{B} \\
\vdots & \ddots & \vdots \\
G_{n 1}^{B} & \cdots & G_{n n}^{B}
\end{array}\right]\left\{\begin{array}{c}
R_{1} \\
\vdots \\
R_{n}
\end{array}\right\}
$$

となる．また，図2（c）の観測点 $r の$ 加速度は

$$
A_{r}^{B}=-\left[\begin{array}{lll}
G_{r 1}^{B} & \ldots & G_{r n}^{B}
\end{array}\right\rfloor\left\{\begin{array}{c}
R_{1} \\
\vdots \\
R_{n}
\end{array}\right\}
$$

と表される.ここで,

$$
\left\{\begin{array}{c}
A_{1}^{A} \\
\vdots \\
A_{n}^{A}
\end{array}\right\}=\left\{\begin{array}{c}
A_{1}^{B} \\
\vdots \\
A_{n}^{B}
\end{array}\right\}
$$

であるから，式（5）に式（2）と式（3）を代入し， $S_{i}=R_{i} / F_{f}$ として整理すると，

$$
\left[\begin{array}{ccc}
G_{11}^{A}+G_{11}^{B} & \cdots & G_{1 n}^{A}+G_{1 n}^{B} \\
\vdots & \ddots & \vdots \\
G_{n 1}^{A}+G_{n 1}^{B} & \cdots & G_{n n}^{A}+G_{n n}^{B}
\end{array}\right]\left\{\begin{array}{c}
S_{1} \\
\vdots \\
S_{n}
\end{array}\right\}=-\left\{\begin{array}{c}
G_{1 f}^{A} \\
\vdots \\
G_{n f}^{A}
\end{array}\right\}
$$

となる.ここで式（6）の $S_{i}$ 以外は伝達関数であり既知であるので, 連立方程式を解き， $S_{i}$ を求める. 求めた $S_{i}$ を 用いて結合点の加速度応答は次式で求められる. 


$$
\left\{\begin{array}{c}
A_{1}^{A} \\
\vdots \\
A_{n}^{A}
\end{array}\right\}=\left[\begin{array}{ccc}
G_{11}^{A} & \cdots & G_{1 n}^{A} \\
\vdots & \ddots & \vdots \\
G_{n 1}^{A} & \cdots & G_{n n}^{A}
\end{array}\right]\left\{\begin{array}{c}
S_{1} \\
\vdots \\
S_{n}
\end{array}\right\} F_{f}+\left\{\begin{array}{c}
G_{1 f}^{A} \\
\vdots \\
G_{n f}^{A}
\end{array}\right\} F_{f}=\left\{\begin{array}{c}
A_{1}^{B} \\
\vdots \\
A_{n}^{B}
\end{array}\right\}=-\left[\begin{array}{ccc}
G_{11}^{B} & \cdots & G_{1 n}^{B} \\
\vdots & \ddots & \vdots \\
G_{n 1}^{B} & \cdots & G_{n n}^{B}
\end{array}\right]\left\{\begin{array}{c}
S_{1} \\
\vdots \\
S_{n}
\end{array}\right\} F_{f}
$$

また，分系 B の内部にある観測点 $r$ 加速度応答も，以下の式（8）で求められる.

$$
A_{r}^{B}=-\left\lfloor\begin{array}{lll}
G_{r 1}^{B} & \ldots & G_{r n}^{B}
\end{array}\right\rfloor\left\{\begin{array}{c}
S_{1} \\
\vdots \\
S_{n}
\end{array}\right\} F_{f}
$$

そこで, 数值解析モデルで分系 A および分系 B の単体をそれぞれ作成し, 加振点 $f$ と結合点に相当する部分を 個別に加振し伝達関数 $G$ を取得する. その後, 式 (7) および式 (8) から結合時の加速度応答を求める. さらに, 数值解析モデルで分系 $\mathrm{A}$ と分系 $\mathrm{B}$ を結合させた図 2 (a) に相当するモデルを作成し, 加振点 $f$ を加振し加速度応 答を求める. 前者は伝達関数合成法で求めた予測結果に相当し, 後者は実際の試験時の応答（正解值）に相当す るため, これら 2 つ方法で求めた応答の比較を行うことで, 伝達関数合成法による予測結果の妥当性を検証す ることができる.

なお，伝達関数 $G$ は並進 3 成分 $\left(T_{x}, T_{y}, T_{z}\right)$ および回転 3 成分 $\left(R_{x}, R_{y}, R_{z}\right)$ の 6 成分を持つため, 加振方 向 $I_{d}\left(I_{d}=T_{x}, T_{y}, T_{z}, R_{x}, R_{y}, R_{z}\right)$ に対する応答方向 $O_{d}\left(O_{d}=T_{x}, T_{y}, T_{z}, R_{x}, R_{y}, R_{z}\right)$ の伝達関数を $g_{o_{d} I_{d}}$ とすると $G_{i j}^{N}$ は以下の式 (9) となる.

$$
G_{i j}^{N}=\left[\begin{array}{llllll}
g_{T_{x} T_{x}}^{N} & g_{T_{x} T_{y}}^{N} & g_{T_{x} T_{z}}^{N} & g_{T_{x} R_{x}}^{N} & g_{T_{x} R_{y}}^{N} & g_{T_{x} R_{z}}^{N} \\
g_{T_{y} T_{x}}^{N} & g_{T_{y} T_{y}}^{N} & g_{T_{y} T_{z}}^{N} & g_{T_{y} R_{x}}^{N} & g_{T_{y} R_{y}}^{N} & g_{T_{y} R_{z}}^{N} \\
g_{T_{z} T_{x}}^{N} & g_{T_{z} T_{y}}^{N} & g_{T_{z} T_{z}}^{N} & g_{T_{z} R_{x}}^{N} & g_{T_{z} R_{y}}^{N} & g_{T_{z} R_{z}}^{N} \\
g_{R_{x} T_{x}}^{N} & g_{R_{x} T_{y}}^{N} & g_{R_{x} T_{z}}^{N} & g_{R_{x} R_{x}}^{N} & g_{R_{x} R_{y}}^{N} & g_{R_{x} R_{z}}^{N} \\
g_{R_{y} T_{x}}^{N} & g_{R_{y} T_{y}}^{N} & g_{R_{y} T_{z}}^{N} & g_{R_{y} R_{x}}^{N} & g_{R_{y} R_{y}}^{N} & g_{R_{y} R_{z}}^{N} \\
g_{R_{z} T_{x}}^{N} & g_{R_{z} T_{y}}^{N} & g_{R_{z} T_{z}}^{N} & g_{R_{z} R_{x}}^{N} & g_{R_{z} R_{y}}^{N} & g_{R_{z} R_{z}}^{N}
\end{array}\right]
$$

\section{3. 数值解析モデルと計算手順}

本検討では, 合成する成分の必要性について，2 種類の数值解析モデルを用いて検討した．1つめは「平板モデ ル」である．単純な形状として平板を 2 枚用意し，それぞれを分系 $\mathrm{A}$ ，分系 $\mathrm{B}$ とし，長手方向につないだモデル を結合時のモデルとした，平板に垂直な方向（ $T_{z}$ 方向）から衝撃を加えた場合の $T_{z}$ 方向の SRS 予測について検討 した. 平板モデルでは衝撃印加および観測方向である $T_{z}$ 方向に対して, $R_{y}$ 方向の曲げ振動も大きな成分をもつこ とが予想される．実環境で計測が困難な回転成分が支配的な場合，SRS の予測結果にどのような影響を及ぼすか 検討するための特殊な状況を想定したモデルであると言える.

2 つめは実試験想定モデル」である。これは落錘式衝撃試験機で小型の電気コンポーネントの衝撃試験を行 う場合を想定したモデルである.試験機の被試験体搭載部は平板をワイヤ等で懸架する形状のものが多い.また, 宇宙機コンポーネントは箱型形状のものが多く, 底面フランジ部を 4 10 か所程度, 㸚じで搭載部に固定するこ とが一般的である。 そこで, 分系 A（試験機側）は平板形状とした．また，分系 B（被試験体側）は箱型構造の 底部を 4 か所固定する形状を模擬しつつ, 可能なかぎり計算コストを下げるため, 4 つの足をもつ平板構造とし た. 分系 $\mathrm{A}$ の平板に垂直な方向（ $T_{z}$ 方向）から衝撃を加えた場合の $T_{z}$ 方向の予測について検討した. この「実試 験想定モデル」は,「平板モデル」よりも構造が複雑であり, 実際の試験に近い状況での検討を行うためのモデル である. 
各有限要素モデルは要素数を少なくすることで伝達関数を求めるための周波数応答解析の計算時間を短縮し, 分系 $\mathrm{A}$ と分系 $\mathrm{B}$ の結合点数を少なくし, 合成計算の計算負荷を下げるため, シェル要素と梁要素を用いてモデル 化した. 数值解析モデルの作成は MSC Patran 2019 Feature Pack 1 により行った. 数值計算ソルバーは MSC Nastran 2019 Feature Pack 1 の線形定常周波数応答解析である Solution sequence 111（SOL 111）を用いた.

\section{$3 \cdot 1$ 平板モデル}

表 1 に平板モデルの各系の諸元と, 図 3 に形状を示す. 平板の材質はアルミ合金 (JIS A 5052) である. 分系 A, B とも $400 \mathrm{~mm} \times 50 \mathrm{~mm}$ の平板で厚みがそれぞれ $9 \mathrm{~mm}$ と $7 \mathrm{~mm}$ である. シェルでモデル化し, 長手方向の要素長 は $10 \mathrm{~mm}$, 短手方向は応答解析の時間短縮と, 結合計算の負荷を下げるため 2 分割とし, 要素長 $25 \mathrm{~mm}$ とした. またモデル端部がフリーフリーの条件では数值解析の制約上，応答計算が困難になることから，軽量かつ剛性の 低い仮想的な梁で懸架する方法を採用した。䀣架梁は断面形状が直径 $1 \mathrm{~mm}$ の円である梁要素とし，全長は 100 $\mathrm{mm}$ で要素長は $10 \mathrm{~mm}$ である. 懸架梁の端部は 6 自由度固定されている. 結合モデルにおいて分系 $\mathrm{A}$ と分系 $\mathrm{B}$ は 3 か所で結合されており, 分系 $\mathrm{A}$ の端部に衝撃を印加したときの, 結合部（観測点 1）と分系 B の端部（観測点 2）の加速度応答を計算した。

Table 1 Parameters used for plate model analysis.

\begin{tabular}{cccc}
\hline Model & Substructure A & Substructure B & Suspension beam \\
\hline \hline Size $(\mathrm{W} \times \mathrm{H} \times \mathrm{T})$ & $400 \times 50 \times 9$ & $400 \times 50 \times 7$ & $\phi 1 \times 100$ \\
{$[\mathrm{~mm}]$} & 69,300 & 69,300 & 69.3 \\
\hline Young's modulus [MPa] & 0.33 & 0.33 & 0.33 \\
\hline Poisson ration [- $]$ & 2680 & 2680 & 1000 \\
\hline Density $\left[\mathrm{kg} / \mathrm{m}^{3}\right]$ & $10 \times 25$ & $10 \times 25$ & 10 \\
\hline Element size $(\mathrm{W} \times \mathrm{H})[\mathrm{mm}]$ & & &
\end{tabular}

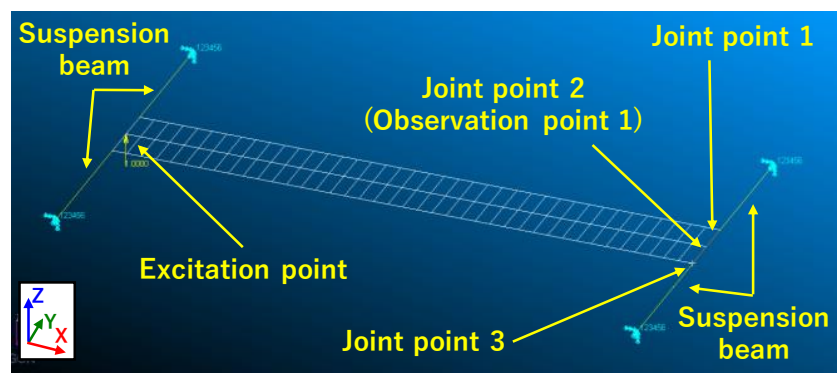

(a) Substructure $\mathrm{A}$

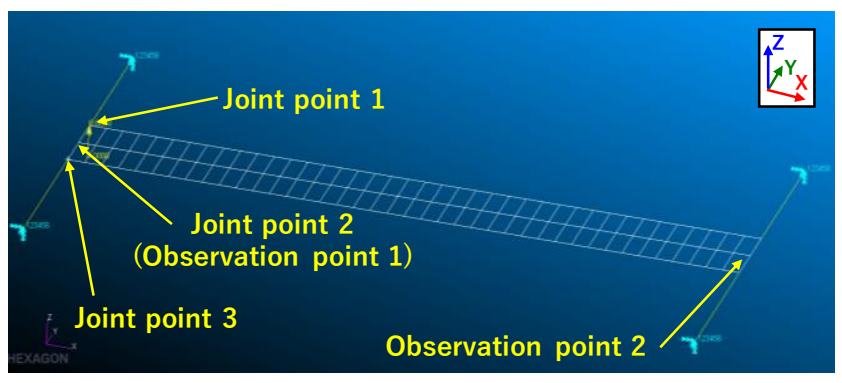

(b) Substructure B

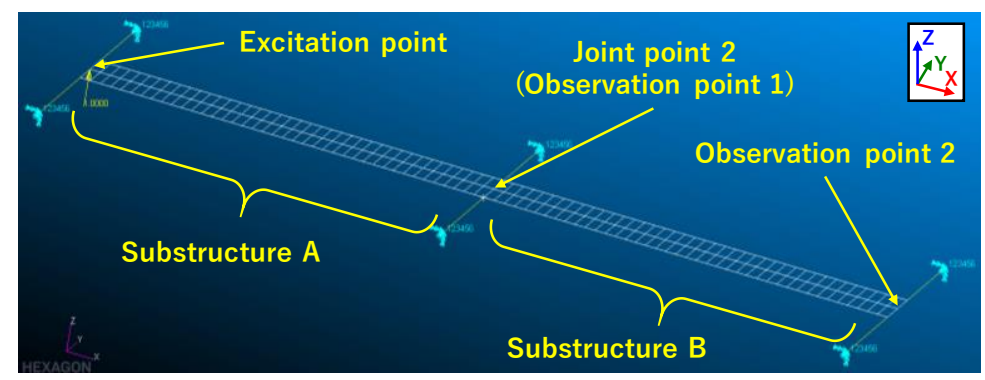

(c) Jointed model

Fig. 3 Numerical analysis model of a "flat plate model" created by MSC Patran ${ }^{\circledR} 2019$ Feature Pack 1. Substructure A is a flat plate $400 \times 50 \times 9 \mathrm{~mm}$, and B is a flat plate $400 \times 50 \times 7 \mathrm{~mm}$. Since the free-free condition make numerical calculations difficult, each structure is suspended on a virtual beam that is lightweight and less rigid. The jointed model consists of the substructure $\mathrm{A}$ and $\mathrm{B}$ connected at three points. The response of the joint point (observation point 1) and the end of B (observation point 2) to an impact to the end of A was predicted. 


\section{$3 \cdot 2$ 実試験想定モデル}

表 2 に実試験想定モデルの各系の諸元と図 4 に形状を示す. 分系 $\mathrm{A}$ は衝撃試験機の被試験体を搭載するべース プレートを想定したモデルであり，平板を懸架した形状である．分系 B は平板と 4 か所で結合する構造の被試験 体を想定したモデルであり，平板の 4 つ角に平板と垂直の方向に L 字アングル形状の足がついた構造である．材 質は全てアルミ合金（JIS A 5052）である. 分系 A，B とも平板の部分は厚さ $5 \mathrm{~mm}$ のシェルとし，分系 B の足部 分は図 4 (b) 中に示す縦横 $25 \mathrm{~mm}$ ，板厚 $5 \mathrm{~mm}$ の断面形状を持つビーム要素とした．また，平板モデルと同様に モデル端部は軽量かつ岡性の低い仮想的な梁で懸架した。懸架梁の材質および形状は平板モデルと同様であり， 分系 $\mathrm{A}$ の 4 つ角と分系 $\mathrm{B}$ の 4 つ角に設置した. 懸架梁の端部は 6 自由度固定されている. 結合モデルにおいて分 系 $\mathrm{A}$ と分系 $\mathrm{B}$ は分系 $\mathrm{B}$ の足部の 4 か所で結合されており，分系 $\mathrm{A}$ の端部に衝撃を印加したときの，衝撃印加点 から遠い側の結合部（観測点 1）と分系 B の平板部中央（観測点 2）の加速度応答を予測した．なお，実際の試験 における衝撃規定点は分系 $\mathrm{A}$ 上の分系 B 結合部直近であるが，今回は計算式を単純にするため，結合点と結合点 近傍の加速度応答はほぼ等しいと仮定し, 分系 $\mathrm{A}$ と分系 B の結合点のうち衝撃印加点から遠い側（観測点 1）と した.

Table 2 Parameters used for shock tester model analysis.

\begin{tabular}{cccc}
\hline Model & Substructure A & Substructure B & Suspension beam \\
\hline \hline $\begin{array}{c}\text { Size }(\mathrm{W} \times \mathrm{H} \times \mathrm{T}) \\
{[\mathrm{mm}]}\end{array}$ & $500 \times 300 \times 5$ & $\begin{array}{c}200 \times 200 \times 50 \\
\text { Plate }(\text { Shell }): 200 \times 200 \times 5 \\
\text { Legs }(\text { Beam }): 25 \times 25 \times 50(\mathrm{t}=5)\end{array}$ & $\phi 1 \times 100$ \\
\hline Young's modulus $[\mathrm{MPa}]$ & 69,300 & 69,300 & 69.3 \\
\hline Poisson ration [- $]$ & 0.33 & 0.33 & 0.33 \\
\hline Density $\left[\mathrm{kg} / \mathrm{m}^{3}\right]$ & 2680 & 2680 & 1000 \\
\hline Element size $(\mathrm{W} \times \mathrm{H})$ & $10 \times 10$ & Shell : $10 \times 10$ & 10 \\
{$[\mathrm{~mm}]$} & & Beam : 10 & \\
\hline
\end{tabular}

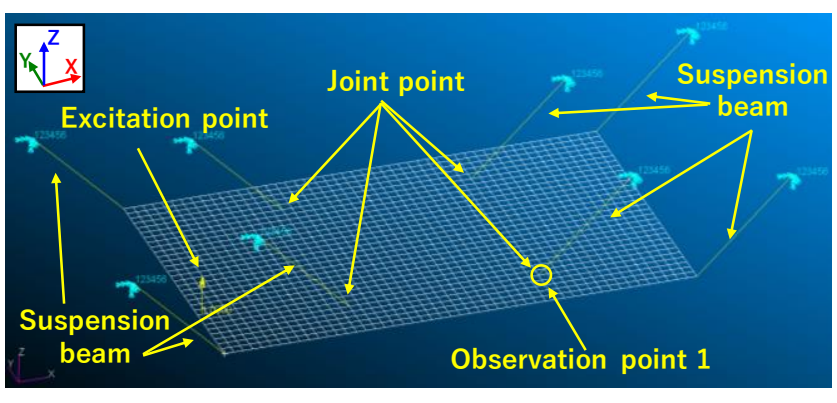

(a) Substructure A

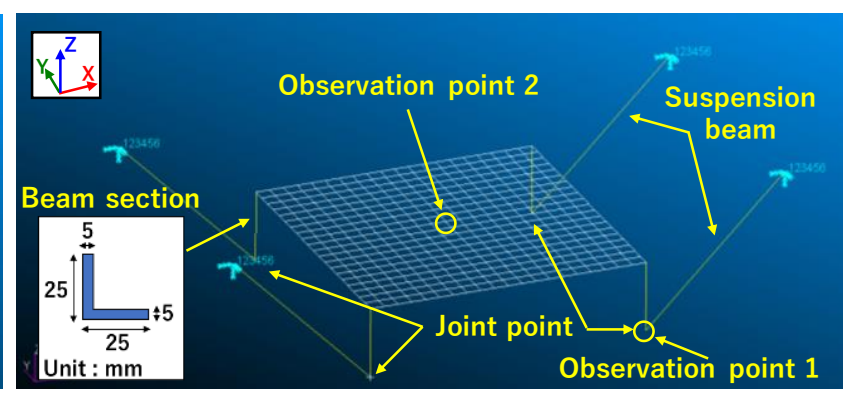

(b) Substructure B

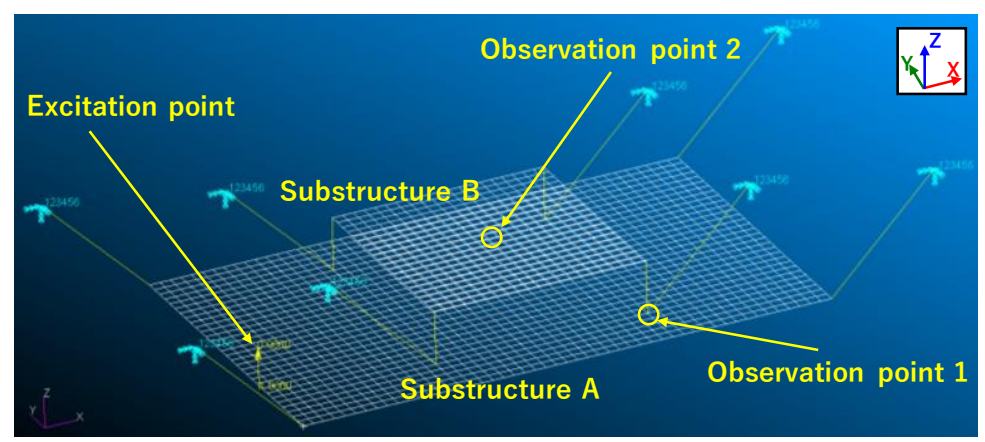

(c) Jointed model

Fig. 4 Numerical analysis model of a "shock tester model". Substructure A is a flat plate $500 \times 300 \times 5$ mm, and substructure B is a flat plate $200 \times 200 \times 50 \mathrm{~mm}$ with four legs. As with the flat plate model, each system is suspended on a virtual beam that is light and less rigid. Substructures A and B each have four binding sites. When an impact is applied to the end of A, the responses of the joint point (observation point 1) far from the excitation point and the center of the plate part of $\mathrm{B}$ (observation point 2) are predicted. 


\section{$3 \cdot 3$ 計算手順}

3.1 節および 3.2 節のモデルで伝達関数合成法を用いて, 衝撃印加点において $T_{z}$ 方向（平板に垂直の方向）に衝 撃を印加した場合の SRS を以下の手順で計算した．数応答計算における減衰比は全振動モードに対して $5 \%$ と た.なお，SRS 解析ではサンプリング周波数は評価したい周波数の 10 倍以上とすることが望ましい. そのため周 波数応答解析の周波数範囲を 0 から $25,000 \mathrm{~Hz}$ ，周波数分解能を $5 \mathrm{~Hz}$ とし，複素数として得られた周波数応答波 形の共役成分を含めて，データ点数を 10,000 点とした. 手順（5）で用いる逆フーリエ変換後の時系列波形のサ ンプリング周波数は周波数分解能とデータ点数の積であり， $50,000 \mathrm{~Hz}$ となる. これにより, SRS は $5,000 \mathrm{~Hz}$ まで 評価できることとなる. 加振のための力関数は並進, 回転ともに周波数応答関数で与え, 0 から $25,000 \mathrm{~Hz}$ までの 全周波数に対して 1.0 を入力する.

(1) 分系 $\mathrm{A}$ の衝撃印加点（Excitation point）を振幅 $1.0 \mathrm{~N}$ の力加振と $1.0 \mathrm{Nm}$ のトルク加振を行い，分系 $\mathrm{A}$ と分 系 $\mathrm{B}$ との結合点の応答を取得することにより式（2）の $G_{n f}^{A}$ を得る.

(2) 分系 $\mathrm{A}$ の分系 $\mathrm{B}$ との結合点を 1 か所ずつ振幅 $1.0 \mathrm{~N}$ の力加振と $1.0 \mathrm{Nm}$ のトルク加振を行い, 各加振にお いて結合点全点の応答を取得することにより式 (2) の $G_{i j}^{A}$ を得る.

(3) 分系 $\mathrm{B}$ の分系 $\mathrm{A}$ との結合点について，上記（2）同様に結合点の応答を取得することにより式（3）の $G_{i j}^{B}$ を得る.

(4) 得られた $G_{n f}^{A}, G_{i j}^{A}$ および $G_{i j}^{B}$ から式 (7) により分系 $\mathrm{A}$ と分系 B の結合点（観測点 1) の応答を得ると共に, 式（8）により分系 $\mathrm{B}$ 上（観測点 2）の応答を得る.

（5）上記（4）で求まる結果は周波数応答であることから，これを高速逆フーリエ変換し時刻歴波形を求め, その後衝撃応答スペクトラム（Smallwood, 1981）を計算する．衝撃応答スペクトラム計算における Q 值 は宇宙機衝撃試験において一般的に用いられる10 とした。

6 成分の全成分について合成を行うためには式（9）に示寸行列を作成する必要がある．そのため，上記（2）お よび (3) の結合点における加振は 6 成分の各方向から行い, 各加振の応答も 6 成分取得する必要がある. 合成す る成分が少ない場合は，それに応じて取得する応答も減少し，式（9）に示寸行列は小さくなる. 本検討では加振 と合成を行う成分は一致させる. 例えば $T_{x}, T_{y}, T_{z}$ の 3 成分合成であれば 3 軸方向の加振を行い，合成する成分 も加振方向の 3 軸のみとする.

計算課程のイメージを図 5 に示す (平板モデルにおける観測点 1 の例). 有限要素モデルの周波数応答解析結 果から取得した伝達関数（図はパワースペクトラム密度であるが実際には複素数）を逆高速フーリエ変換し，時 系列応答を得て SRS 解析を行う.

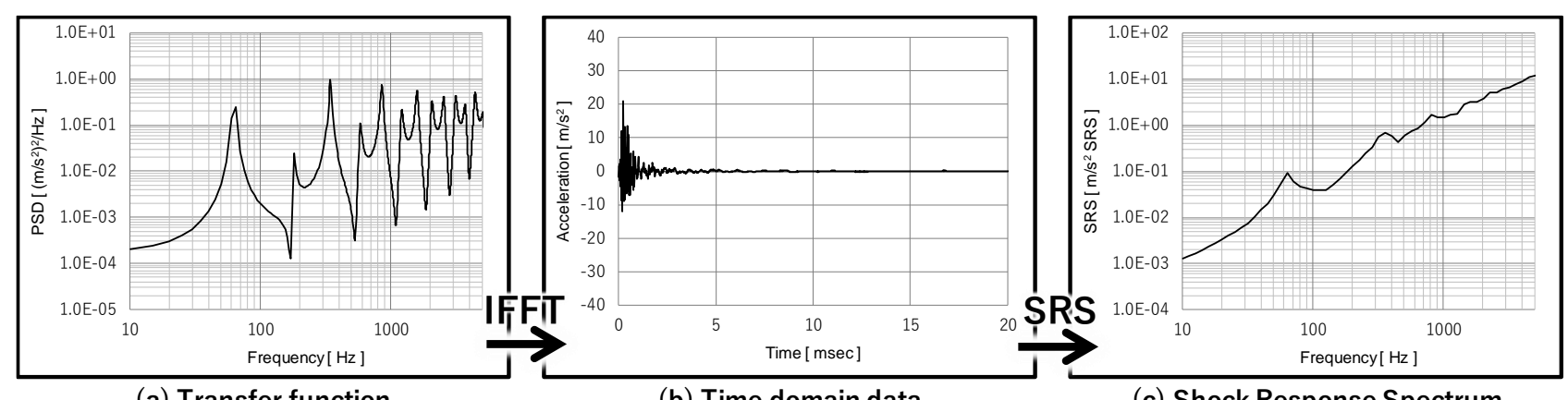

(a) Transfer function (b) Time domain data (c) Shock Response Spectrum

Fig. 5 The process of data conversion. The transfer function obtained from the frequency response analysis of a finite element model. (This figure shows the power spectrum density, but it is actually complex value.) Inverse fast Fourier transform of the transfer function to obtain the time domain response. And SRS analysis is performed. 


\section{4. 合成成分と衝撃予測結果}

\section{$4 \cdot 1$ 平板モデル}

平板モデルにおける衝撃応答の予測結果を図 6 および図 7 に示す. 図 6 （a）は 6 成分を合成した結果であり, 図 6 (b) は平板の振動モードにおいて支配的と考えられる並進 1 成分 $\left(T_{z}\right)$ および回転 2 成分 $\left(R_{x}, R_{y}\right)$ の 3 成 分を合成した結果である. 図 7 は試験により伝達関数を取得する場合を想定し，一般的な加速度センサで取得可 能な並進方向のみを合成したものであり, 図 7 (a) は並進 3 成分 $\left(T_{x}, T_{y}, T_{z}\right)$ について, 図 7 (b) は並進 1 成 分 $\left(T_{z}\right)$ のみを用いて合成した結果である. 各図中の黒破線は分系 $\mathrm{A}$ と分系 $\mathrm{B}$ を結合させた状態で計算した正解 值であり, 赤実線は伝達関数合成法による計算結果である. 図には正解值に対して NASA の衝撃試験規格 (NASA, 2011）に定める試験公差である $\pm 6 \mathrm{~dB}$ の範囲と，宇宙機衝撃試験で一般的な周波数範囲（100 から $4,000 \mathrm{~Hz} ）$ も あわせて示す。

図 6 (a) より 6 成分の合成結果は正解值と予測值がほぼ一致しており伝達関数合成法による予測が正確に行え ることがわかる. 図 $6(\mathrm{~b})$ より $T_{z}, R_{x}, R_{y}$ の 3 成分の合成結果も正解值とほぼ同等となっている. 一方, 図 7 (a) に示寸 $T_{x}, T_{y}, T_{z}$ の並進 3 成分の合成結果は, $100 \mathrm{~Hz}$ 以上の周波数では概衩正解值 $\pm 6 \mathrm{~dB}$ の範囲内の結果となっ ているものの，図6に示寸結果よりも合わない結果となった。 また，図 7 (b) に示寸 $T_{z}$ 並進 1 成分のみの合成結 果は並進 3 成分の合成結果と同等となっている．そこで， $T_{z}, R_{y}$ の 2 成分で合成した結果を図 8 に示す．この 2 成分の合成結果は 6 成分合成の結果と同等であり, 平板モデルにおいては, $T_{z}, R_{y}$ の 2 成分が支配的であり，そ の他の軸は合成結果に影響しないことを示している.

よって，今回用いた平板モデルにおいては $T_{z} ， R_{y}$ の 2 成分が支配的であり，その他の軸は影響しないことがわ かった。このような衝撃印加方向ではない回転方向に卓越した成分を持つモデルの場合は，並進成分のみの合成 結果の予測精度に問題がある場合，並進方向の合成成分を増やしたとしても予測精度の向上が見込めない. よっ て，並進加速度のみのデータ取得で予測精度を向上させることに限界があることがわかる。しかしながら，実際 の試験において平板モデルのようなコンフィギュレーションとなることはほとんどないと考えられる.

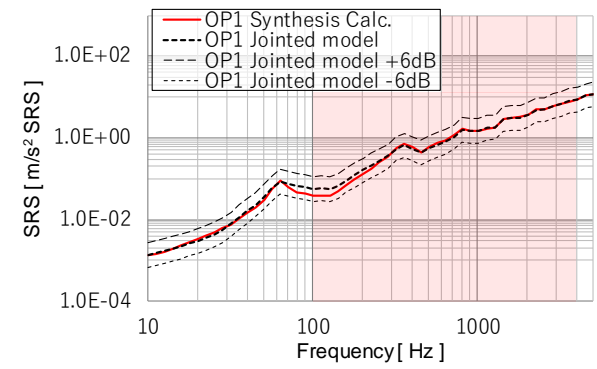

(a1) Observation point 1

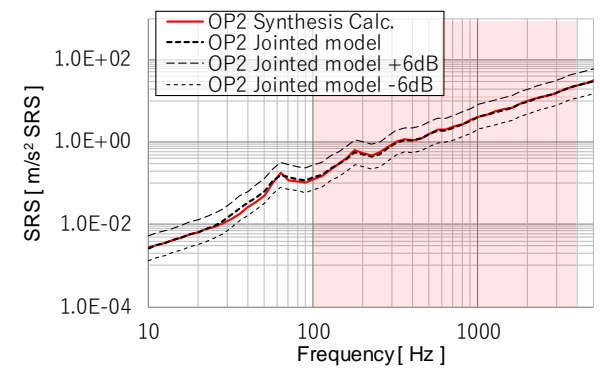

(a2) Observation point 2

(a) 6DOF Synthesis of the plate model

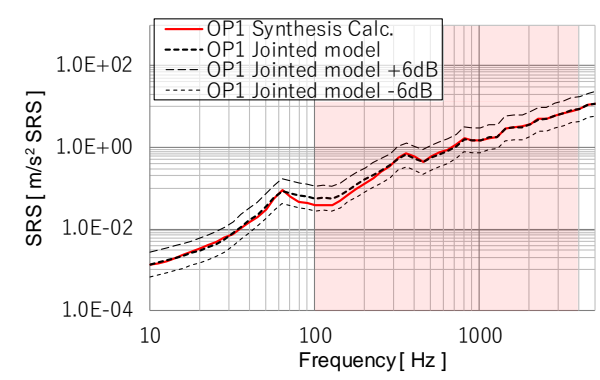

(b1) Observation point 1

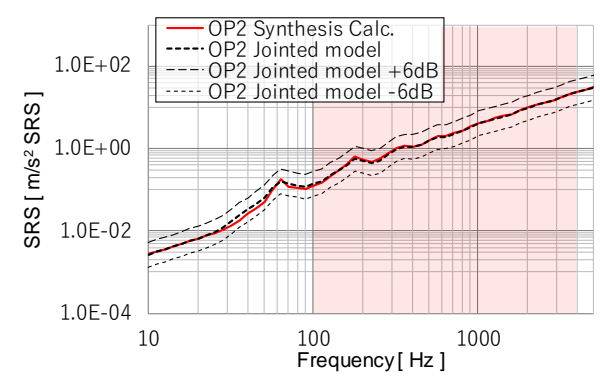

(b2) Observation point 2

(b) 3DOF (Tz, Rx, Ry) Synthesis of the plate model

Fig. 6 Calculated SRS of the plate model. (a) is a composite result of all six-axes, and (b) is a composite result of three axes, namely, one translational axis (Tz) and two rotational axes (Rx and Ry), which are considered to be dominant in the vibration mode of the flat plate. Each figure is overlaid with the correct value (black dashed lines) and the result of the synthesis method (red solid lines). The SRS figure shows a range of $\pm 6 \mathrm{~dB}$ from the correct value and the frequency range $(100-4000 \mathrm{~Hz})$ commonly used for spacecraft shock test specifications. 


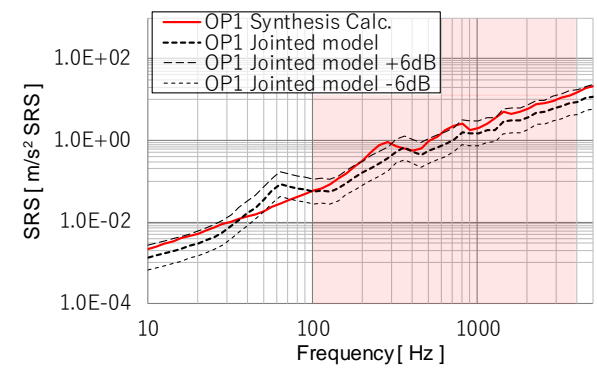

(a1) Observation point 1

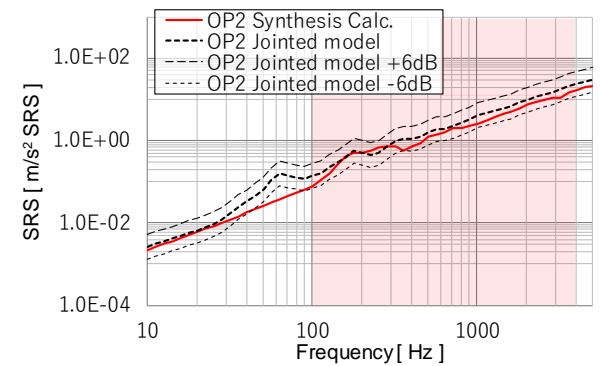

(a2) Observation point 2

(a) 3DOF (Tx, Ty, Tz) Synthesis of the plate model

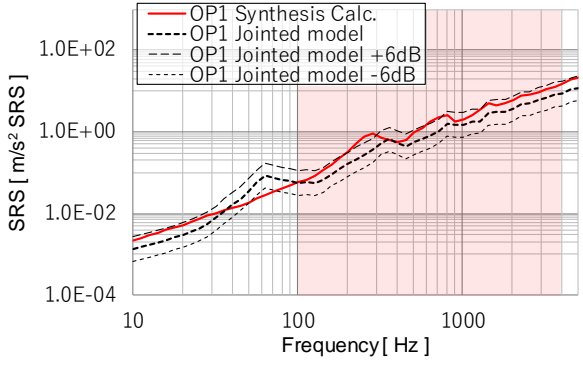

(b1) Observation point 1

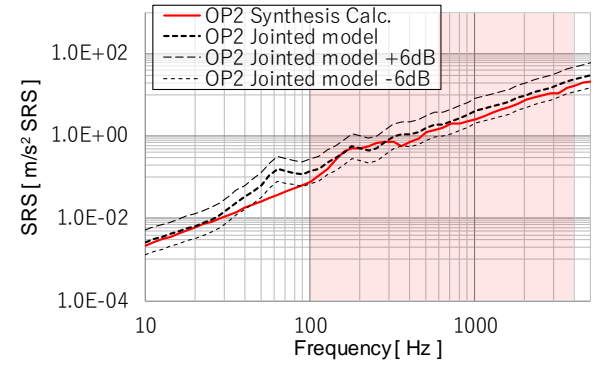

(b2) Observation point 2

(b) 1DOF (Tz) Synthesis of the plate model

Fig. 7 Calculated SRS of the plate model. (a) is a composite result of three translational axes (Tx, Ty and Tz), and (b) is a composite result of one translational axis $(\mathrm{Tz})$ only.

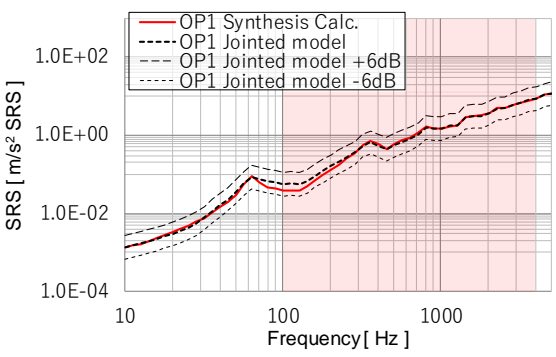

(a) Observation point 1

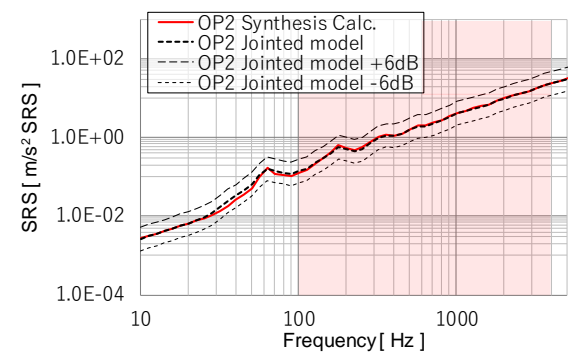

(b) Observation point 2

2DOF (Tz, Ry) Synthesis of the plate model

Fig. 8 Calculated SRS of the plate model. Composite result of two axes (Tz and Ry).

\section{$4 \cdot 2$ 実試験想定モデル}

実試験想定モデルにおける衝撃応答の予測結果を図 9 および図 10 に示す. 平板モデルの場合と同様，図 9 (a) は 6 成分, 図 $9(\mathrm{~b})$ は並進 1 成分 $\left(T_{z}\right)$ および回転 2 成分 $\left(R_{x}, R_{y}\right)$, 図 10 (a) は並進 3 成分 $\left(T_{x}, T_{y}, T_{z}\right)$, 図 $10(\mathrm{~b})$ は並進 1 成分 $\left(T_{Z}\right)$ のみの合成結果である. 6 成分の合成結果は正解值と予測值がほぼ一致した。 3 成 分の合成では，回転成分を含む予測結果も並進 3 成分から予測した結果も，観測点 2 おいて一部正解值 $+6 \mathrm{~dB}$ を 上回っているものの，概ね正解值 $\pm 6 \mathrm{~dB}$ の範囲内となった．さらに，並進 1 成分のみの計算結果は，観測点 2 お いて一部正解值 $-6 \mathrm{~dB}$ を下回っているものの，概ね正解值士 $6 \mathrm{~dB}$ 以内となった.

衝撃試験を実施する観点では，衝撃規定点の応答を予測できることが重要である．衝撃規定点である観測点 1 について各成分の影響を詳しく見るため， $T_{z}$ 成分とそれ以外の各軸成分による 2 成分合成計算を行った. 図 11 に 結果を示す. 2 成分合成の結果は，各軸で若干の差異が認められるものの，概ね $T_{z}$ 成分のみの合成結果と同様の 計算結果となっている.

実試験想定モデルは平板モデルと比較すると，衝撃規定点においては $T_{Z}$ 成分が支配的であり，SRS を子測する 際には並進 1 成分のみを採用した予測結果も良好な結果となっている. 衝撃規定点で $T_{z}$ 成分が支配的となるのは, 
平板に箱型構造を締結した場合，結合点の曲げ剛性が高くなるからであると考えられる。これは一般的な衝撃試 験のコンフィギュレーションでも同様である. よって, 実際の試験においても並進 1 成分のみの合成で問題ない と考えられる.

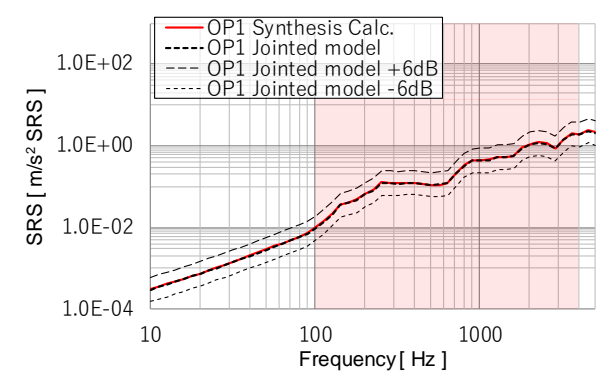

(a1) Observation point 1

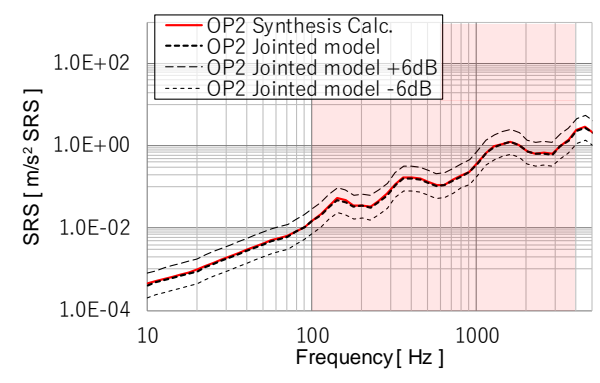

(a2) Observation point 2

(a) 6DOF Synthesis of the shock tester model

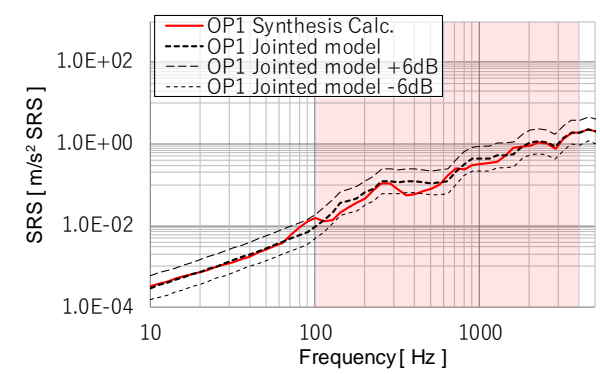

(b1) Observation point 1

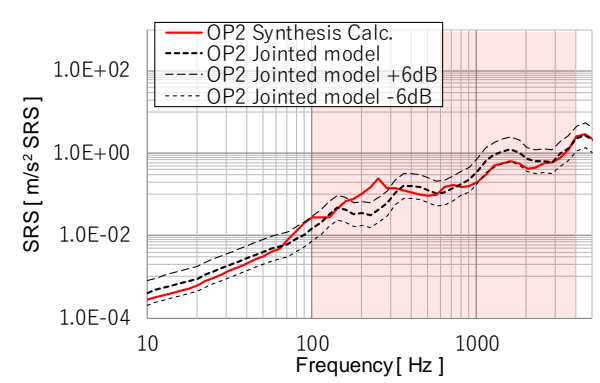

(b2) Observation point 2

(b) 3DOF (Tz, Rx, Ry) Synthesis of the shock tester model

Fig. 9 Calculated SRS of the shock tester model. (a) is a composite result of all six-axes, and (b) is a composite result of three axes (Tz, Rx and Ry).

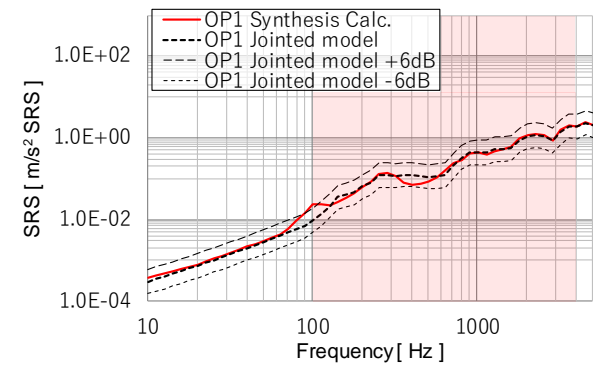

(a1) Observation point 1

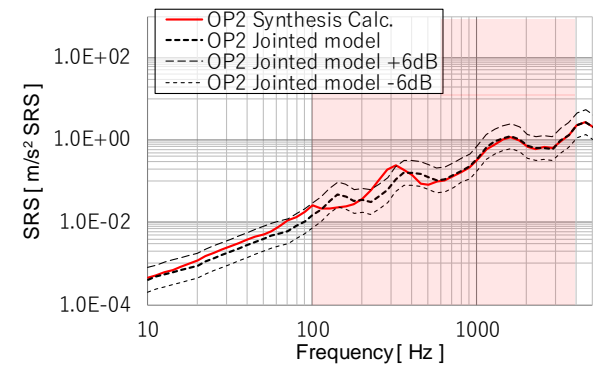

(a2) Observation point 2

(a) 3DOF (Tx, Ty, Tz) Synthesis of the shock tester model

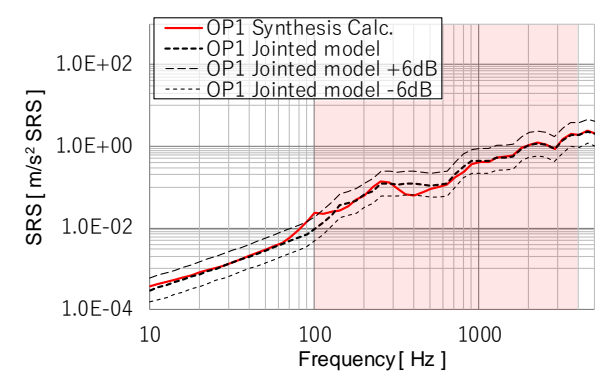

(b1) Observation point 1

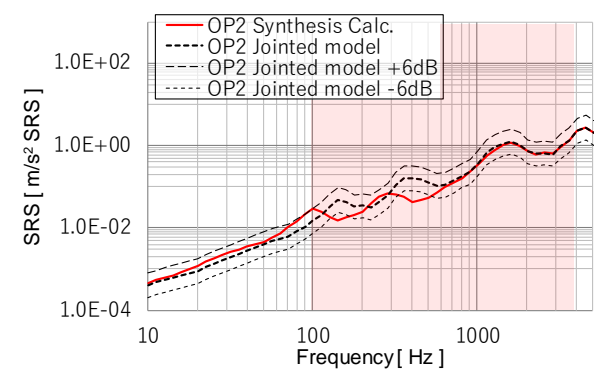

(b2) Observation point 2

(b) 1DOF (Tz) Synthesis of the shock tester model

Fig. 10 Calculated SRS of the shock tester model. (a) is a composite result of three translational axes (Tx, Ty and Tz), and (b) is a composite result of one translational axis $(\mathrm{Tz})$ only. 


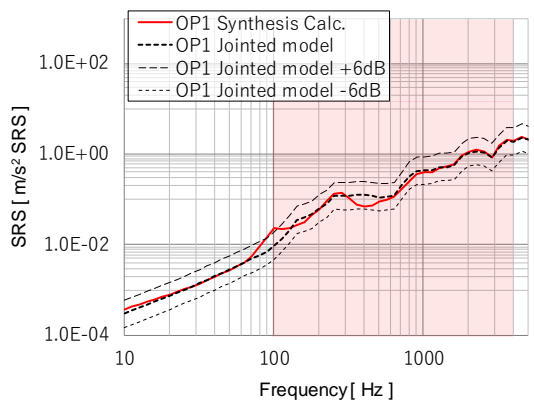

(a) Tx, Tz synthesis

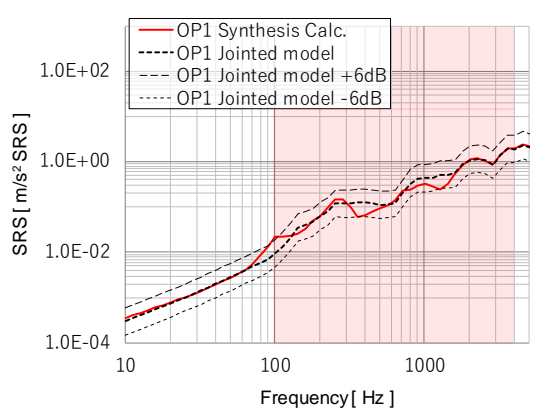

(d) Tz, Rx synthesis

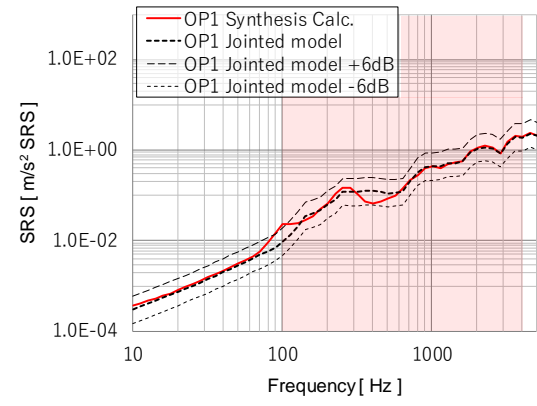

(b) Ty, Tz synthesis

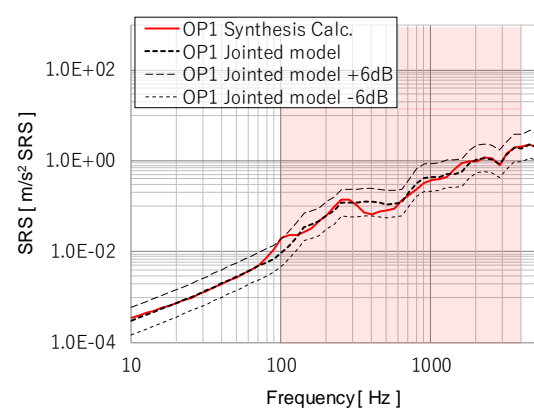

(e) Tz, Ry synthesis

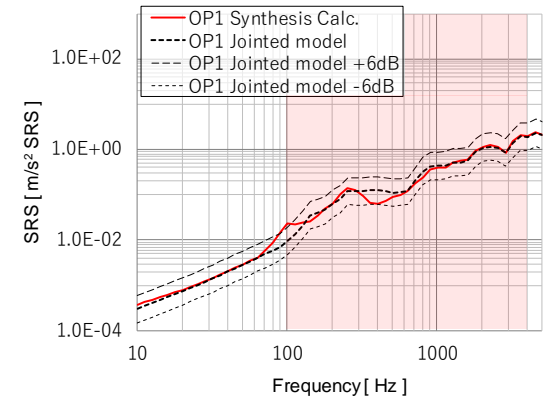

(c) Tz synthesis

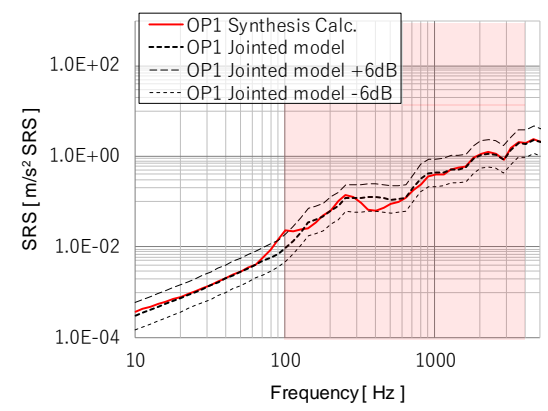

(f) Tz, Rz synthesis

Fig. 11 Calculated SRS of the shock tester model. (a) is a composite result of two axes (Tx and Tz), (b) is Ty and Tz, (c) is Tz only, (d) is Tz and Rx, (e) is Tz and Ry and (f) is Tz and Rz.

\section{5. 周波数応答の比較}

SRS の正解值と計算結果との差異の要因をより詳細に考察するため, 周波数応答関数での比較を行う. 図 12 お よび図 13 は平板モデルにおける分系 $\mathrm{A}$ と分系 B を結合させた状態で計算した正解值と，伝達関数合成法による 計算結果の周波数応答 (パワースペクトル密度) の比較である. 黒破線が正解值, 赤実線が合成計算結果である. 図 12 (a) は 6 成分, 図 12 (b) は並進 1 成分 $\left(T_{z}\right)$ および回転 2 成分 $\left(R_{x}, R_{y}\right)$, 図 13 (a) は並進 3 成分 $\left(T_{x}\right.$, $\left.T_{y}, T_{z}\right)$, 図 $13(\mathrm{~b})$ は並進 1 成分 $\left(T_{z}\right)$ のみの合成結果である. また, 図 14 および 15 については実試験想定モ デルにおける同様の比較結果である.

平板モデルでは，6成分合成（図 12 (a) ) と回転 2 成分を含む 3 成分合成（図 12 (b)）の結果はほぼ一致して いる.これは，4.1節の図 8 の結果からもわかる通り，平板構造において $T_{Z}$ 方向に加振した場合に支配的な成分が $T_{z}$ および $R_{y}$ であるためと考えられる. 並進 3 成分による合成（図 13 (a)）では $R_{y}$ 成分を取り込んでいないため, 正解值との乘離が発生しており，特に $65 \mathrm{~Hz}$ にある 1 次共振のピークが合成結果からは見えなくなってしまって いる． $T_{z}$ のみの並進 1 成分合成（図 $13(\mathrm{~b})$ ) についても並進 3 成分の合成と同様である. これらの結果から，平 板のような曲げ振動が支配的となる形状においては，加速度センサによって取得される並進成分のみの合成によ って予測精度を上げることが困難な場合があると言える。

次に実試験想定モデルの周波数応答をみると，6成分合成（図 14 (a) ) は，低周波数帯まで非常によく一致し ている．対して，回転 2 成分を含む 3 成分合成（図 14 (b) )，並進 3 成分による合成（図 15 (a)）および並進 1 成分合成（図 15 (b)）は $1000 \mathrm{~Hz}$ 以下の領域において, 共振点の周波数がずれるような結果となっているものの, ピーク值については概数正解值と一致している，その結果，SRS に変換した際の結果がある程度一致したと考え られる. 4.2 節の図 11 で示したとおり, 実試験想定モデルでは特に衝撃規定点において, 衝撃を印加する方向 $\left(T_{z}\right)$ の応答が支配的である。これは，平板に箱型の構造を設置した場合，結合部の曲げ剛性が大きくなることが原因 と考えられ，実際の試験でも同様と考えられる．よって，衝撃試験において衝撃規定点の予測を行う場合は，並 進 1 成分のみの結果を用いた伝達関数合成によって十分な結果が得られると考えられる. 
なお，数值解析ではなく，実際にハンマリング試験等で伝達関数を取得する場合，斜め打ちや印加位置のずれ に注意する必要がある．また，2 章に示寸合成計算は各分系の結合点は剛としているが，実際の締結点は完全な 剛ではない，今後は，これら実際の試験で課題となる事項の影響について検討をす寸める必要がある.

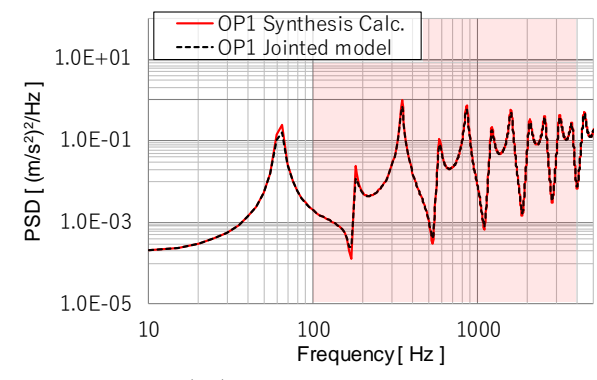

(a1) Observation point 1

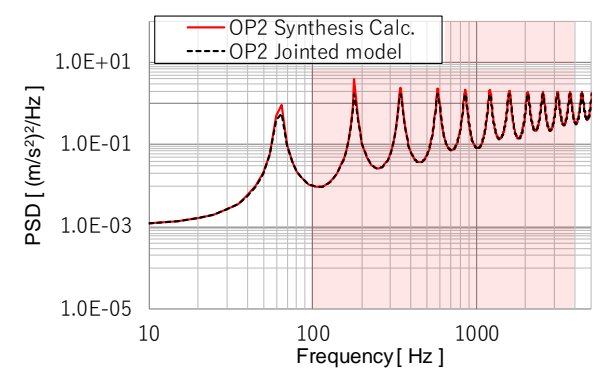

(a2) Observation point 2

(a) 6DOF Synthesis of the plate model

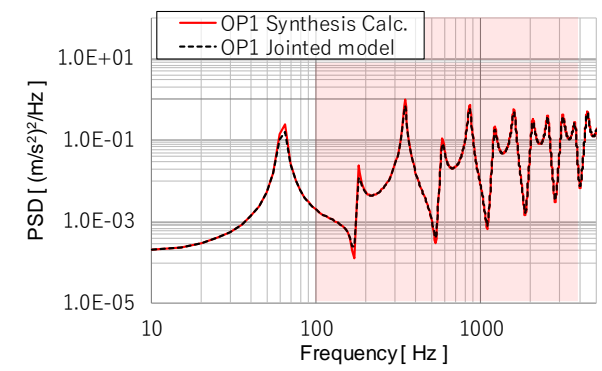

(b1) Observation point 1

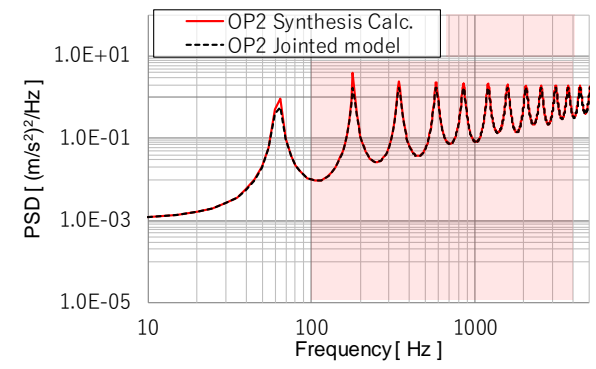

(b2) Observation point 2

(b) 3DOF (Tz, Rx, Ry) Synthesis of the plate model

Fig. 12 Calculated frequency response spectrum (power spectrum density) of the plate model. (a) is a composite result of all sixaxes, and (b) is a composite result of three axes (Tz, Rx and Ry). Each figure is overlaid with the correct value (black dashed lines) and the result of the synthesis method (red solid lines).

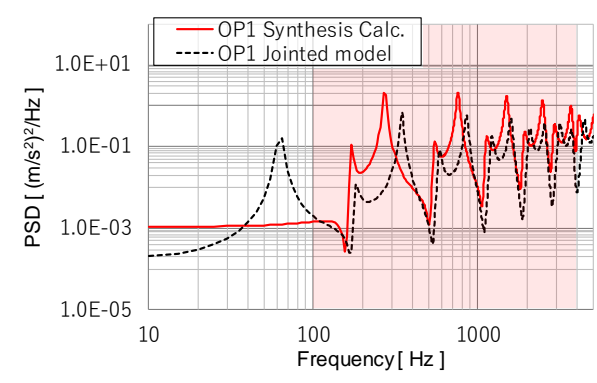

(a1) Observation point 1

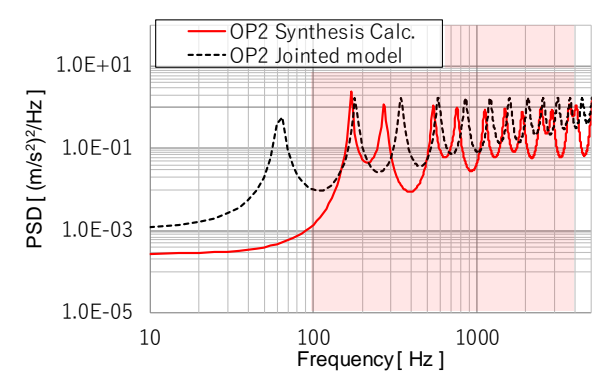

(a2) Observation point 2

(a) 3DOF (Tx, Ty, Tz) Synthesis of the plate model

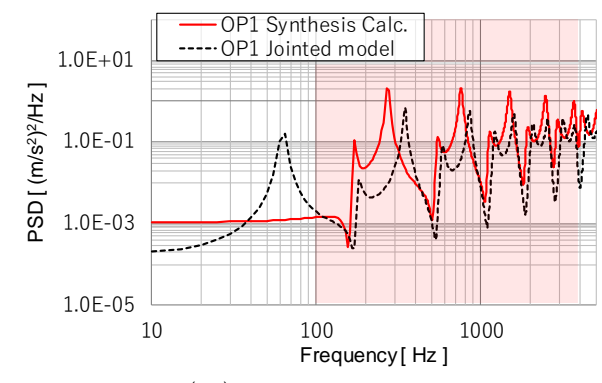

(b1) Observation point 1

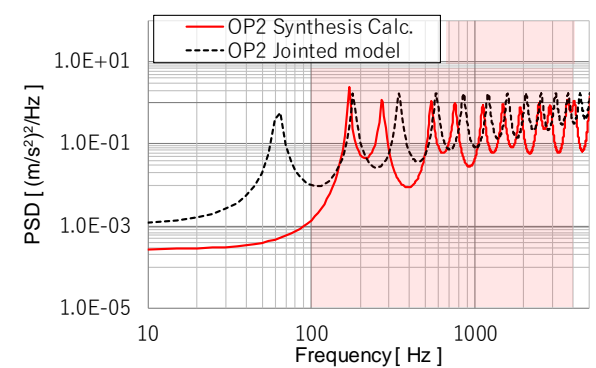

(b2) Observation point 2

(b) 1DOF (Tz) Synthesis of the plate model

Fig. 13 Calculated frequency response spectrum (power spectrum density) of the plate model. (a) is a composite result of three translational axes (Tx, Ty and Tz), and (b) is a composite result of one translational axis (Tz) only. 


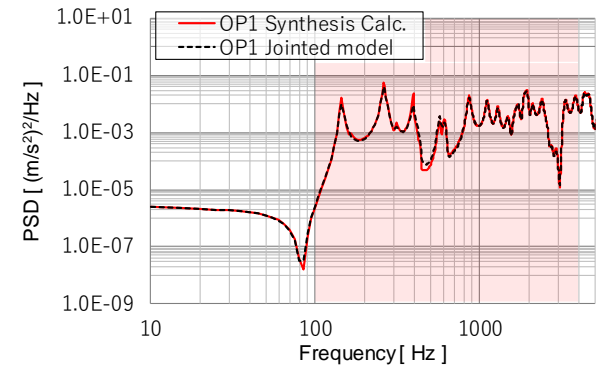

(a1) Observation point 1

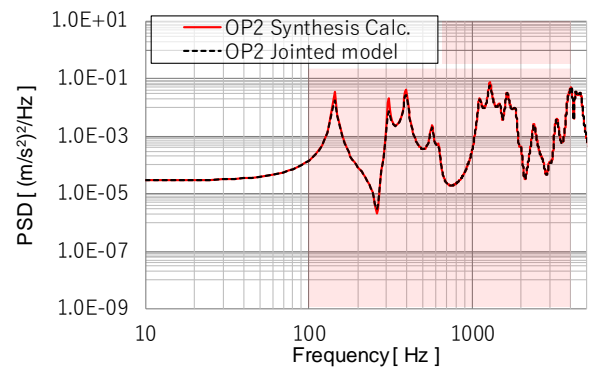

(a2) Observation point 2

(a) 6DOF Synthesis of the shock tester model

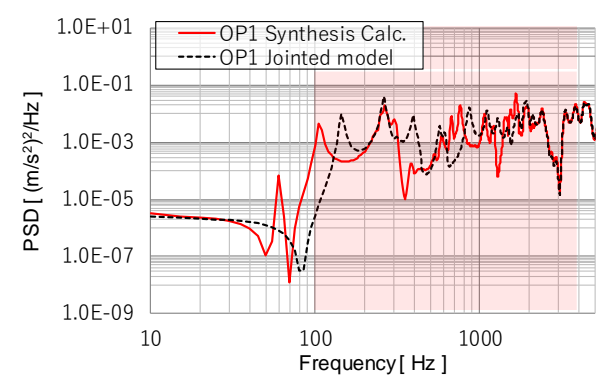

(b1) Observation point 1

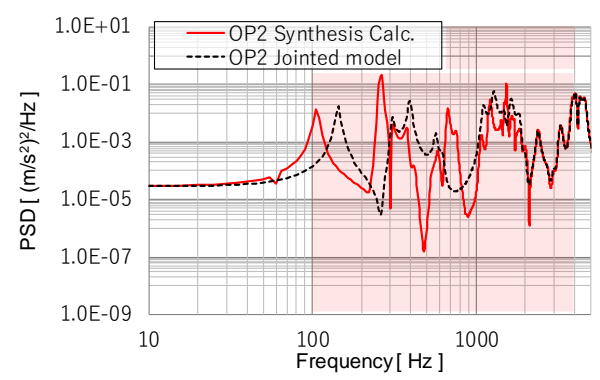

(b2) Observation point 2

(b) 3DOF (Tz, Rx, Ry) Synthesis of the shock tester model

Fig. 14 Calculated frequency response spectrum (power spectrum density) of the shock tester model. (a) is a composite result of all six-axes, and (b) is a composite result of three axes (Tz, Rx and Ry).

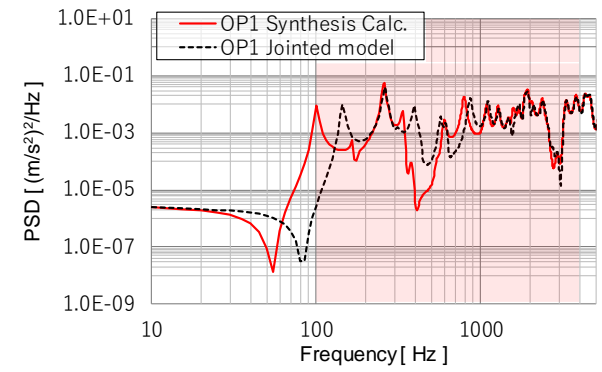

(a1) Observation point 1

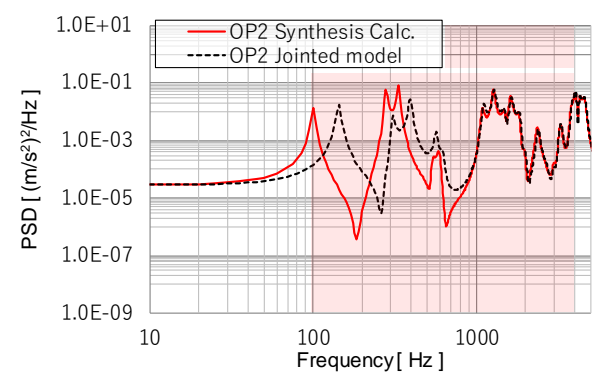

(a2) Observation point 2

(a) 3DOF (Tx, Ty, Tz) Synthesis of the shock tester model

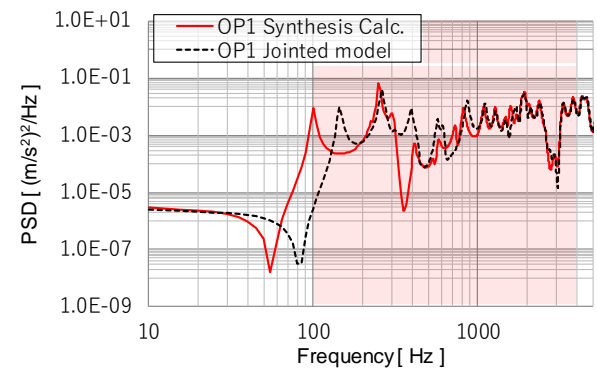

(b1) Observation point 1

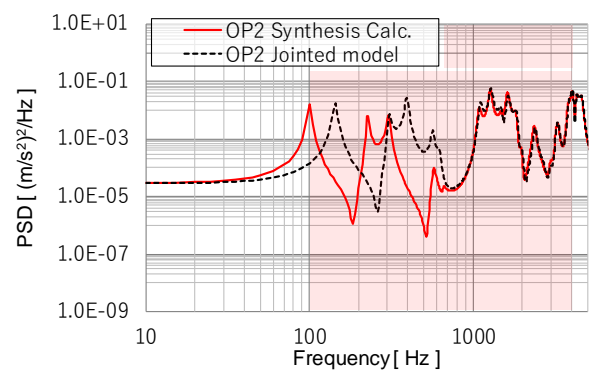

(b2) Observation point 2

(b) 1DOF (Tz) Synthesis of the shock tester model

Fig. 15 Calculated frequency response spectrum (power spectrum density) of the shock tester model. (a) is a composite result of three translational axes (Tx, Ty and Tz), and (b) is a composite result of one translational axis (Tz) only. 


\section{6. 結 言}

伝達関数合成法を用いて被試験体搭載時に試験機上で発生する SRS を事前に予測する場合に, 実用上どのよう な成分について合成を行うべきか数值解析モデルを用いて検討した．平板のような曲げ振動が顕著なモデルでは 並進成分のみの合成では予測精度の向上が困難な場合があることが分かった。一方，実際の衝撃試験機を想定し たモデルにおいては，試験機搭載板は平板であり，そこに箱型コンポーネントを設置するというコンフィギュレ ーションであり，衝撃規定点近傍では並進成分が支配的となるため，衝撃を印加する並進方向のみの合成でも十 分な予測ができることが示された。これは実際の衝撃試験でも同様と考えられる．以上より，実際の試験で衝撃 規定点の SRS を予測する場合, 衝撃印加方向のみの伝達関数を取得し, 合成することによって, 利便性と精度を 両立させた予測が可能であると考えられる，今後は，実際の試験で伝達関数を取得し，有效性について検討を進 める予定である.

\section{謝 辞}

本研究の実施にあたり，鳥取大学工学部機械物理系学科固体力学研究室卒業生の岸本拓也氏の協力に心より感 謝申しあげます．また，本研究は JSPS 科学研究費助成金，課題番号 18 K04570の支援を受けたものです.

\section{文献}

Iwasa, T. and Shi, Q., Simplified estimating method for shock response spectrum envelope of v-band clamp separation shock, Journal of space engineering, Vol. 1, No. 1 (2008), pp.46-57.

宇宙航空研究開発機構, 衝撃試験ハンドブック, JERG-2-130-HB001, A 改訂版 (2017), p.32.

Lee, J. R., Chia, C. C. and Kong, C. W., Review of pyroshock wave measurement and simulation for space systems, Measurement, Vol. 45, Issue 4 (2012), pp.631-642.

Lee, S. J., Hwang, D. H. and Han, J. H., Development of pyroshock simulator for shock propagation test, Shock and vibration, Vol. 2018, Article ID 9753793 (2018).

Nagamatsu, A., Nakao, A., Iwamoto, T. and Nagaike, M., Analysis of vibration by substructure synthesis method (Part.1 bacic approach), Bulletin of the JSME, Vol. 26, No. 219 (1983), pp.1635-1640.

長松昭男, 大熊政明, 部分構造合成法, 培風館 (1991), pp.91-93.

National Aeronautics and Space Administration (NASA), Pyroshock test criteria, NASA-STD-7003, revision A (2011), p.27.

沖津昭慶，山下健治，畔上秀幸，回転自由度を考慮した実験的動剛性結合法，日本機械学会論文集 C 編，Vol.54， No. 505 (1988), pp.2059-2064.

Smallwood, D. O., An improved recursive formula for calculating shock response spectra, Shock and vibration bulletin, No. 51 (1981), pp.211-217.

Wang, X., Qin, Z., Ding, J. and Chu, F., Finite element modeling and pyroshock response analysis of separation nuts, Aerospace science and technology, Vol. 68 (2017), pp.380-390.

柳瀬恵一, 福田達輝, 岸本拓也, 岩佐貴史, 小畑良洋, 宇宙機コンポーネント衝撃試験における衝撃応答スペクト ラムの事前予測手法の検討, 第 28 回スペース・エンジニアリング・コンファレンス講演論文集, No.19-344, $\mathrm{C} 02$ (2019).

\section{References}

Iwasa, T. and Shi, Q., Simplified estimating method for shock response spectrum envelope of v-band clamp separation shock, Journal of space engineering, Vol. 1, No. 1 (2008), pp.46-57.

Japan Aerospace Exploration Agency, Shock test handbook, JERG-2-130-HB001, revision A (2017), p.32 (in Japanese).

Lee, J. R., Chia, C. C. and Kong, CW., Review of pyroshock wave measurement and simulation for space systems, Measurement, Vol. 45, Issue 4 (2012), pp.631-642.

Lee, S. J., Hwang, D. H. and Han, J. H., Development of pyroshock simulator for shock propagation test, Shock and vibration, Vol. 2018, Article ID 9753793 (2018). 
Nagamatsu, A., Nakao, A., Iwamoto, T. and Nagaike, M., Analysis of vibration by substructure synthesis method (Part.1 bacic approach), Bulletin of the JSME, Vol. 26, No. 219 (1983), pp.1635-1640.

Nagamatsu, A. and Okuma, M., Component mode synthesis, Baifukan (1991), pp.91-93 (in Japanese).

National Aeronautics and Space Administration (NASA), Pyroshock test criteria, NASA-STD-7003, revision A (2011), p.27.

Okitsu, A., Yamashita, K. and Azegami, H., Substructure synthesis method with consideration of rotational effects on the combined boundary, Transactions of the Japan Society of Mechanical Engineers, Series C, Vol. 54, No. 505 (1988), pp.2059-2064 (in Japanese).

Smallwood, D. O., An improved recursive formula for calculating shock response spectra, Shock and vibration bulletin, No. 51 (1981), pp.211-217.

Wang, X., Qin, Z., Ding, J. and Chu, F., Finite element modeling and pyroshock response analysis of separation nuts, Aerospace science and technology, Vol. 68 (2017), pp.380-390.

Yanagase, K., Fukuda, T., Kishimoto, T., Iwasa, T. and Obata, Y., Prediction method of shock response spectrum in spacecraft component shock test, Proceedings of 28th JSME Space engineering conference, No.19-344, C02 (2019) (in Japanese). 